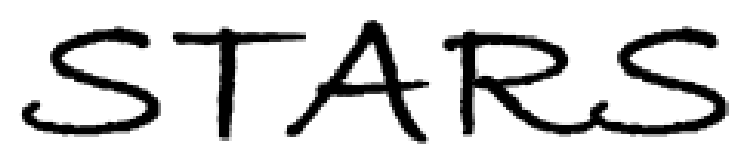

University of Central Florida

STARS

Faculty Bibliography 2000s

Faculty Bibliography

$1-1-2006$

\title{
Managing fire-prone forests in the western United States
}

\author{
Reed F. Noss \\ University of Central Florida \\ Jerry F. Franklin \\ University of Central Florida \\ William L. Baker \\ Tania Schoennagel \\ Peter B. Moyle
}

Find similar works at: https://stars.library.ucf.edu/facultybib2000

University of Central Florida Libraries http://library.ucf.edu

This Review is brought to you for free and open access by the Faculty Bibliography at STARS. It has been accepted for inclusion in Faculty Bibliography 2000s by an authorized administrator of STARS. For more information, please contact STARS@ucf.edu.

\section{Recommended Citation}

Noss, Reed F.; Franklin, Jerry F.; Baker, William L.; Schoennagel, Tania; and Moyle, Peter B., "Managing fireprone forests in the western United States" (2006). Faculty Bibliography 2000s. 6479.

https://stars.library.ucf.edu/facultybib2000/6479

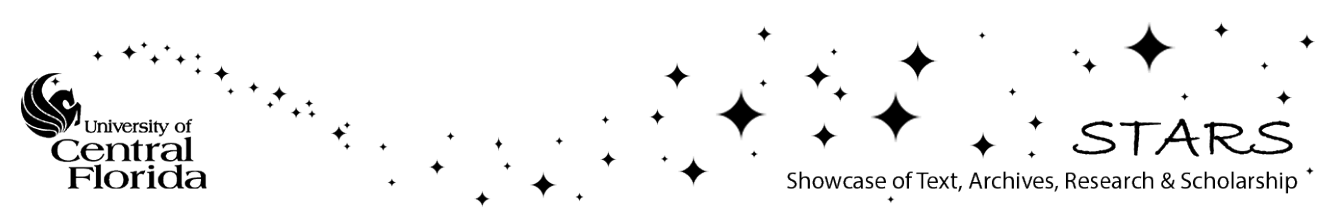




\title{
Managing fire-prone forests in the western United States
}

\author{
Reed F Noss ${ }^{1}$, Jerry F Franklin ${ }^{2}$, William L Baker ${ }^{3}$, Tania Schoennagel ${ }^{4}$, and Peter B Moyle ${ }^{5}$
}

The management of fire-prone forests is one of the most controversial natural resource issues in the US today, particularly in the west of the country. Although vegetation and wildlife in these forests are adapted to fire, the historical range of fire frequency and severity was huge. When fire regimes are altered by human activity, major effects on biodiversity and ecosystem function are unavoidable. We review the ecological science relevant to developing and implementing fire and fuel management policies for forests before, during, and after wildfires. Fire exclusion led to major deviations from historical variability in many dry, low-elevation forests, but not in other forests, such as those characterized by high severity fires recurring at intervals longer than the period of active fire exclusion. Restoration and management of fire-prone forests should be precautionary, allow or mimic natural fire regimes as much as possible, and generally avoid intensive practices such as post-fire logging and planting.

$\mathrm{T}$ he management of fire-prone forests, especially within the national forests of the west, is one of the most contentious natural resource issues in the US today. One recent response to the controversy is the Healthy Forests Restoration Act (HFRA) of 2003 (Public Law 108-V148). This law has potentially profound consequences for forests and their biodiversity and must therefore be implemented on the basis of the best scientific information and guidance. Towards this end, the North American Section of the Society for Conservation Biology convened a scientific panel to review issues related to the ecology and management of fire-prone forests of the western US. This article is adapted from the unpublished report of that panel (Noss et al. 2006a).

The vegetation of North America has been shaped by

\section{In a nutshell:}

- The complexity created by variability in fire regimes defies a one-size-fits-all management prescription

- Restoration is warranted where fire exclusion has led to substantial alterations in ecosystem qualities

- Post-fire logging usually has no ecological benefits and many negative impacts; the same is often true for post-fire seeding

- Although many forests will require continued management, a common sense conservation goal is to achieve forests that are low maintenance and require minimal repeated treatment

${ }^{1}$ Department of Biology, University of Central Florida, Orlando, FL 32816 (rnoss@mail.ucf.edu); ${ }^{2}$ College of Forest Resources, University of Washington, Seattle, WA 98195; ${ }^{3}$ Ecology Program and Department of Geography, University of Wyoming, Laramie, WY 82071; ${ }^{4}$ Department of Geography, University of Colorado, Boulder, CO 80309; ${ }^{5}$ Department of Wildlife, Fish, and Conservation Biology, University of California, Davis, CA 95616 recurring fires over millions of years. Fossils of pines (Pinus spp), which are closely associated with fire, date from the Cretaceous Period, more than 100 million years ago (Millar 1998). Fire remains the primary natural disturbance influencing plant and animal communities across much of the continent today (Habeck and Mutch 1973; Agee 1993). Many forests, however, have been degraded over the past century by misguided fire management, as well as other impacts such as logging and livestock grazing. Uncharacteristic fuel loads contribute to altered fire regimes in some forest types (Covington and Moore 1994; Schoennagel et al. 2004). Key structural elements (eg old "veteran" trees), terrestrial and aquatic biodiversity, and habitats of many threatened and endangered species are already greatly diminished and at continuing risk of loss. Increased human habitation of wildlands has intensified problems of managing fire, especially at the wildland-urban interface (Dombeck et al. 2004).

For this paper we evaluated the scientific literature that is relevant to conservation, restoration, and management of forests in the western US (excluding Alaska). Our review addresses ecological science relevant to developing and implementing fire and fuel management policies, including activities conducted before, during, and after wildfires. Our focus is primarily on wildlands, rather than the wildland-urban interface, where ecological values may be secondary to fire-risk mitigation to protect people and homes (DellaSala et al. 2004). In wildlands especially, sustainable forest management must be based on well-grounded ecological principles.

\section{Fire in western forests}

Fire provides fundamental services, including recycling nutrients, regulating the density and composition of 


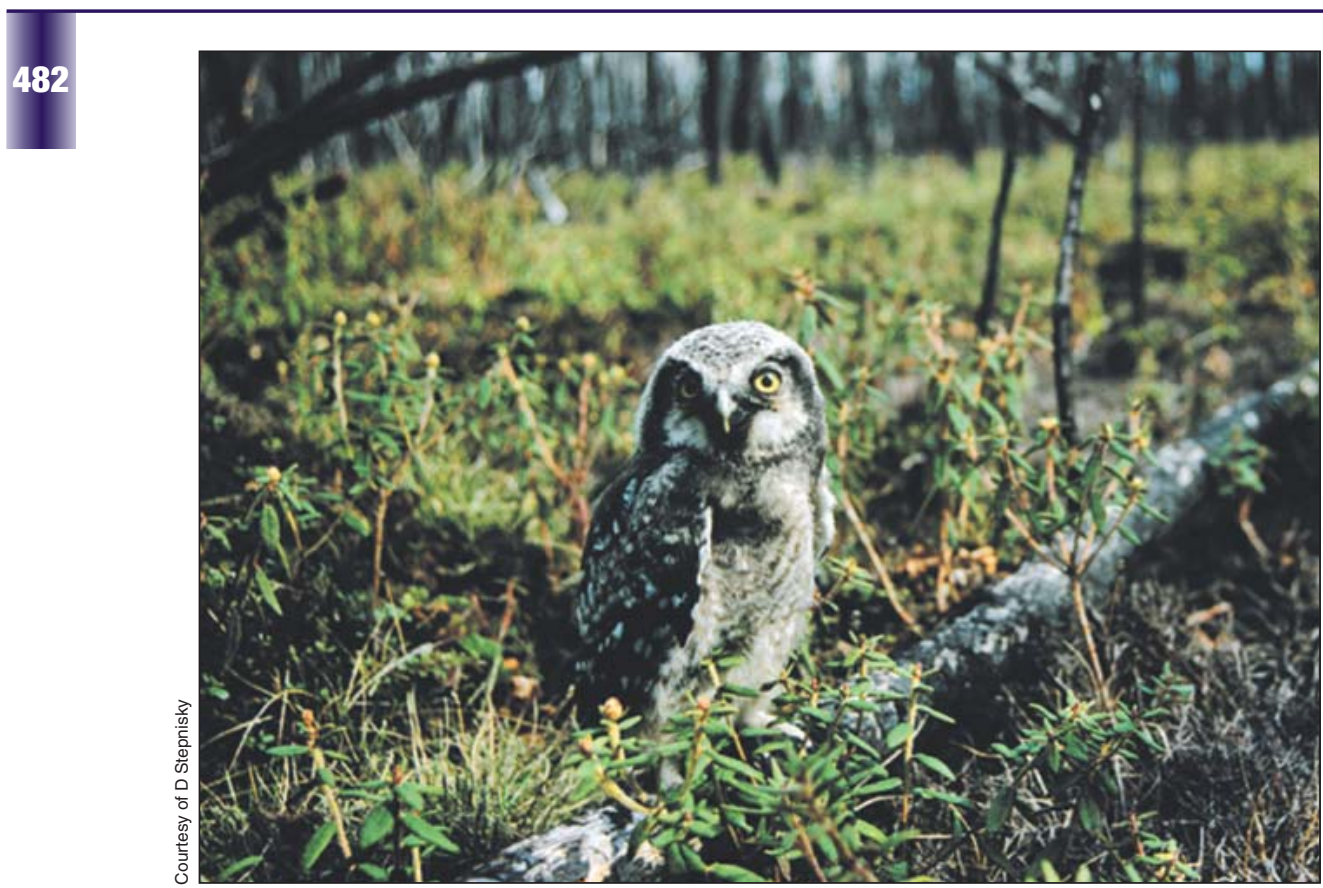

Figure 1. A juvenile northern hawk owl (Surnia ulula) in a recently burned boreal forest. This species and a number of other North American birds are closely associated with post-fire forests and are typically absent from unburned or salvage-logged forests. recur in western forests from once a decade or less in some dry ponderosa pine (Pinus ponderosa) forests to a cycle of 250-400 years or more in coastal forests (Hemstrom and Franklin 1982; Covington et al. 1997; Agee 1998). Even within a forest type, fire frequency may vary by two orders of magnitude across sites, for example, from 6 to 600 years in redwood (Sequoia sempervirens) forests (Noss 2000). Frequent fires are typically lower in intensity (energy output) and severity (impact on vegetation) than infrequent fires, such as those that occurred in and around Yellowstone National Park in 1988 (Turner et al. 2003).

Characteristic fire regimes (Panel 1) result from a combination of forest type, fuels, topography, climate, and ignition sources (Schoennagel et al. 2004). Forests subject to high severity fire typically support high tree densities. When dense fuels dry out and an young trees, creating and shaping wildlife and fish habitat, structuring the spatial pattern of landscapes, and influencing water and sediment delivery across watersheds. Many plant and animal species are adapted to postfire conditions, and populations of some (eg many bird species; Figure 1) decline after fire exclusion or post-fire logging (Hutto 1995). Different species benefit from different fire severities and intervals between fires.

Given fuel, lightning, and dry weather, wildfire is inevitable. Nevertheless, the characteristic fire regime, especially the extent and severity of fire and how often it recurs, varies over a surprisingly large spectrum. Fires

\section{Panel 1. What are "characteristic" and "uncharacteris- tic" fire regimes?}

"Characteristic" is a controversial concept among ecologists. We use this term in reference to the dominant natural disturbance regime and associated structural characteristics for a particular forest type or site historically, before major disruption by EuroAmericans. Conversely, the term "uncharacteristic" refers to disturbances, forest structure, or fuel loads of a scale or type outside the historical range of variability, based on site-specific vegetation reconstructions using tree rings, fire scars, pollen, charcoal, or early historical records. Characteristic does not imply uniformity, because substantial variability occurs within as well as among forest types in fire regime and structure. A forest type that was "historically characterized" by low severity fire may, on many sites, experience high or moderate severity fire (Ehle and Baker 2003). What is characteristic also changes over time, sometimes radically, for example with changing climate (Pierce et al. 2004). Despite difficulties with the concept, some idea of the characteristic fire regime for a given forest is needed, to give management strategies proper direction. ignition source is present, the resulting fires can spread rapidly and are almost impossible to suppress. High severity fires kill most or all trees in substantial portions of the burn, although fire pattern is often a mosaic that includes areas of unburned or less severely burned forest (Figure 2 ). This is true in such diverse forests as productive coastal Douglas-fir (Pseudotsuga menziesii; Agee 1993) and low productivity, high elevation lodgepole pine (Pinus contorta) in the Rocky Mountains (Wallace 2004). Many large, high severity fires are associated with infrequent, severe droughts (Westerling et al. 2003), often related to broad-scale climatic anomalies (Gedalof et al. 2005). Fire exclusion has had minimal effect on most forests characterized by high severity fire - a fact that is especially relevant to fire policy. High severity fires are infrequent (from one to many centuries; Romme and Despain 1989; Agee 1993; Kipfmueller and Baker 2000), whereas the period of active fire exclusion in North America is 50 years at most. Furthermore, many of these forests are remote and occur at high elevations, making access for fire fighting difficult.

In contrast, dry, less productive forests may have annual droughts that promote frequent fires. As a consequence of lower productivity and higher fire frequencies, fuel accumulations and fire intensities are characteristically lower in such forests than in coastal or subalpine forests. Lowseverity fire regimes characterized many pine and mixedconifer forests at warm, dry sites prior to European settlement (Table 1). Fires in ponderosa pine and dry, mixed-conifer forests historically burned fine fuels (eg grasses and litter on the forest floor) at regular intervals (Veblen et al. 2000; Heyerdahl et al. 2001; Stephens and Collins 2004). These surface fires rarely killed large, fire- 
resistant trees, but did kill smaller trees of all species, thereby helping to maintain sparse, open stands. Human activities following European settlement including fire exclusion, grazing, logging, and tree planting - dramatically modified the fuel structure in these forests. Grazing reduced the fine fuels that carry surface fires and facilitated dense tree reproduction by reducing or eliminating herbaceous competition (Rummell 1951; Savage and Swetnam 1990; Belsky and Blumenthal 1997). Logging also promoted higher stand densities in many dry ponderosa pine forests by stimulating dense natural regeneration (Agee 1993; Kaufmann et al. 2000). These forests therefore changed from relatively open stands with low fuel loadings to dense stands that can carry crown fires (Skinner 1995). Restoration of such forests (ie guiding their composition, structure, and function to a condition within the

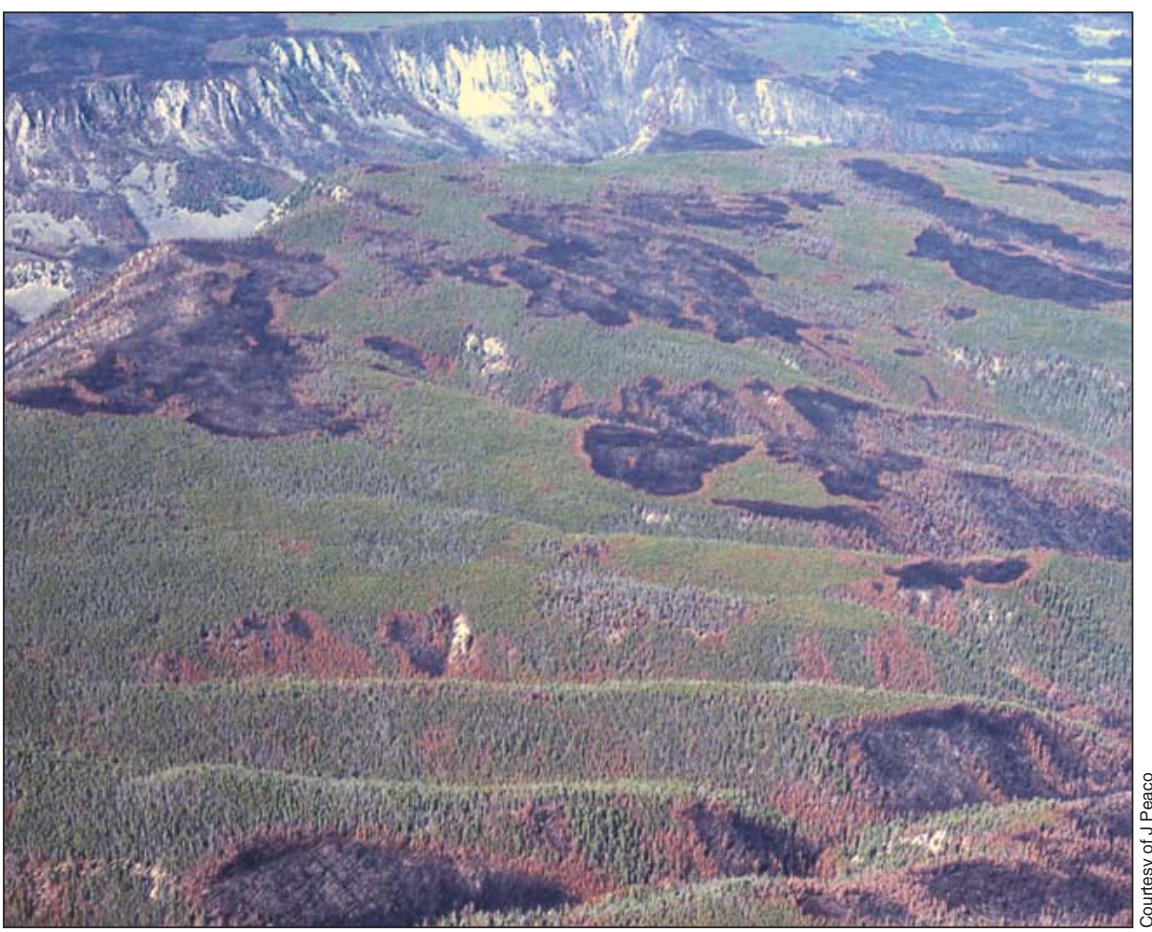

Figure 2. A mosaic fire pattern in Madison Canyon, Yellowstone National Park, approximately one year after the major 1988 fires. historical range of variability) is often desirable (Figure 3) and can involve active techniques such as thinning of small trees and prescribed burning or passive management such as allowing natural fires to burn and removing livestock (Allen et al. 2002; Brown et al. 2004; Schoennagel et al. 2004). Large wildland landscapes are especially well-suited to passive restoration (Noss et al. 2006b).

Fire is variable in severity in certain mid- and low-elevation forests of moderate to high productivity. In addition to the effects of shifts in the weather during a fire, variable fire severity can result from spatial heterogeneity in topography (which affects microclimate), the relative abundance of fuels, and the legacies of past episodes of fire and other disturbances. Topographically complex mountain landscapes may be especially prone to mixed severity fire, because drier, south-facing slopes with lower fuel loads may burn at low severity while adjacent, moister, northfacing slopes that support higher tree densities experience high severity fire (Taylor and Skinner 2003; Spies et al. 2006) or escape fire due to wetter conditions. Evidence of mixed severity fire in moist ponderosa pine forests and mixed evergreen-conifer forests is accumulating (Shinneman and Baker 1997; Brown et al. 1999; Odion et al. 2004). The inherent variability of mixed-severity fire regimes precludes easy analysis of fire-exclusion effects, because high tree density or an abundance of shade-tolerant trees is not necessarily the result of fire exclusion.

The complexity created by variability in fire regimes defies a simple, one-size-fits-all prescription for restoration. Fortunately, plant association groups, which have predictable relationships to fire regimes (Table 1), provide a classification of this diversity that is useful for man- agers, albeit plant association-fire relationships can be expected to change as climate changes (McKenzie et al. 2004; Pierce et al. 2004).

\section{Forest management prior to wildfire}

How can forests be managed to ensure that fire will play its characteristic role in maintaining composition, structure, and function of forest ecosystems? Management will vary greatly with the type of forest and its dominant fire regime (Table 1). Developing a management and restoration program requires that the effects of past land uses be identified so that they can be remedied. In forests characterized by low-severity fire regimes, restoration varies along a continuum from restoring structure (eg reducing densities of small trees and increasing the density of large trees) to restoring the processes (eg low severity fire, competition between grasses and tree seedlings) that create and maintain that structure (Figure 4). The continuum also represents a gradient from symptoms (eg uncharacteristically high tree densities) to causes (eg exclusion of fire). The following are some of our key findings that relate to decisions about fire management. (1) Fire exclusion and other human activities led to significant deviations from historical variability in some, but not all, forests. Restoration treatments are warranted, sometimes urgently, only where such activities have resulted in major alterations in ecosystem structure, function, or composition. (2) Fire exclusion has had little effect on fuels or forest structure in forests characterized by high severity (standreplacement) fire. High severity fires are relatively infrequent, occurring at intervals of one to many centuries, 


\begin{tabular}{|c|c|c|}
\hline Dominant fire type(s) & General forest type & Common plant association groups \\
\hline \multirow[t]{5}{*}{ High severity } & Coastal temperate forests & $\begin{array}{l}\text { Sitka spruce, western hemlock, } \\
\text { western red cedar, Douglas-fir }\end{array}$ \\
\hline & Coastal subalpine forests & Mountain hemlock, Pacific silver fir \\
\hline & Pinyon pine-juniper woodlands & $\begin{array}{l}\text { Colorado pinyon, singleleaf pinyon, } \\
\text { Utah juniper, western juniper }\end{array}$ \\
\hline & Interior Northwest montane forests & $\begin{array}{l}\text { White pine, western red } \\
\text { cedar, western hemlock }\end{array}$ \\
\hline & Interior subalpine forests & $\begin{array}{l}\text { Engelmann spruce-subalpine fir, } \\
\text { lodgepole pine, bristlecone pine, } \\
\text { limber pine, whitebark pine, } \\
\text { quaking aspen }\end{array}$ \\
\hline \multirow[t]{6}{*}{ Mixed severity } & Coastal oak woodlands & \\
\hline & $\begin{array}{l}\text { Rocky Mountain ponderosa pine- } \\
\text { Douglas-fir forests }\end{array}$ & $\begin{array}{l}\text { Ponderosa pine, Douglas-fir, } \\
\text { western larch }\end{array}$ \\
\hline & Interior mesic mixed conifer forests & Douglas-fir, white fir, aspen \\
\hline & $\begin{array}{l}\text { Klamath-Siskiyou mixed evergreen } \\
\text { forests }\end{array}$ & \\
\hline & Sierra Nevada red fir forests & Shasta red fir \\
\hline & Sierra Nevada giant sequoia forests & Giant sequoia \\
\hline \multirow[t]{2}{*}{ Low severity } & Dry ponderosa pine forests & Ponderosa pine, Jeffrey pine \\
\hline & Dry mixed conifer forests & $\begin{array}{l}\text { Ponderosa pine, Douglas-fir, dry } \\
\text { grand fir }\end{array}$ \\
\hline \multicolumn{3}{|c|}{ Sources: Agee 1993, 1998; Arno 2000} \\
\hline
\end{tabular}

whereas active fire exclusion, especially in remote forests, began only decades ago. Because fuel structures or tree densities are usually within the historical range of variability, active restoration is ecologically inappropriate in these forests. (3) Restoration of dry ponderosa pine and dry mixedconifer forests - where low severity fires were historically most common - is ecologically appropriate on many sites. Active (eg mechanical thinning of small stems, prescribed fire) or passive (eg wildland fire use, livestock removal) management can restore stand densities to the levels that existed prior to fire exclusion, livestock grazing, logging, and plantation establishment. Retention of old live trees, large snags, and large logs in restoration treatments is critical. Also, restoring other key components of these ecosystems, such as native understory plants, is essential for full recovery of natural conditions, including the characteristic fire regime. (4) Scientific understanding of mixed severity fire regimes is limited, making it difficult to provide defensible guidelines for restoration. These are often complex landscape mosaics; it is therefore necessary to plan and conduct activities at large spatial scales. Where sufficient ecological and fire-history information is available, a combination of thinning and prescribed fire may be useful in restoration. Nevertheless, only portions of these landscapes may warrant treatment. (5) Restoration plans should systematically incorporate fire to maintain restored forests. Forests are dynamic; therefore, any restoration program must provide for sustained fire management to maintain the desired condition. Low-maintenance forests, which can often be achieved through managed natural fire, are an appropriate restoration goal in many cases; where this is not possible, prescribed fire should mimic the characteristic fire regime as closely as possible. Because fire regimes vary tremendously on a regional scale, managers should allow for a range of fire severities. (6) Species closely associated with late- or early-successional conditions in fire-prone landscapes need special management consideration. For example, managed forests are often fragmented by periodic logging and road-building, or consist only of stands of trees too small or too open to meet the needs of late-successional dependent species, such as the spotted owl (Strix occidentalis).

\section{Forest management during wildfire}

Fire management policies focus on responses to wildfire, including such basic decisions as whether to suppress it. A generalized policy of fire suppression is inappropriate given the documented negative ecological impacts of fire suppression during the 20th century. Responses to fire must take into consideration many ecological and social factors, beginning with the nature of the forest type and societal goals.

Our findings indicate that allowing fires to serve their natural role is ecologically beneficial. Although fire must be managed when close to human infrastructure, in many wilderness areas, national parks, and large areas of public land there is opportunity to increase the use of wildland fire. Such management benefits species that require the shifting mosaics of post-fire habitats found in natural landscapes (Smucker et al. 2005). Furthermore, fire suppression may be ecologically warranted in some cases, particularly where special values are at risk. For example, it may be appropriate where habitat of critically imperiled species could be lost, where uncharacteristic fuel accumu- 
lations have created the potential for a fire outside the historical range of variability, or where high severity fires are not now viewed as ecologically desirable (eg old-growth forests in the Pacific Northwest). Finally, ecologists should be included on fire management teams to ensure that decisions consider the ecological costs and benefits of management actions.

\section{Forest management after wildfire}

Forest landscapes that have been affected by a major natural disturbance, such as a severe wildfire or wind storm, are commonly viewed as devastated. Such perspectives are usually far from ecological reality. Overall species diversity, measured as number of species - at least of higher plants and vertebrates - is often highest following a natural standreplacement disturbance and before redevelopment of closed-canopy forest

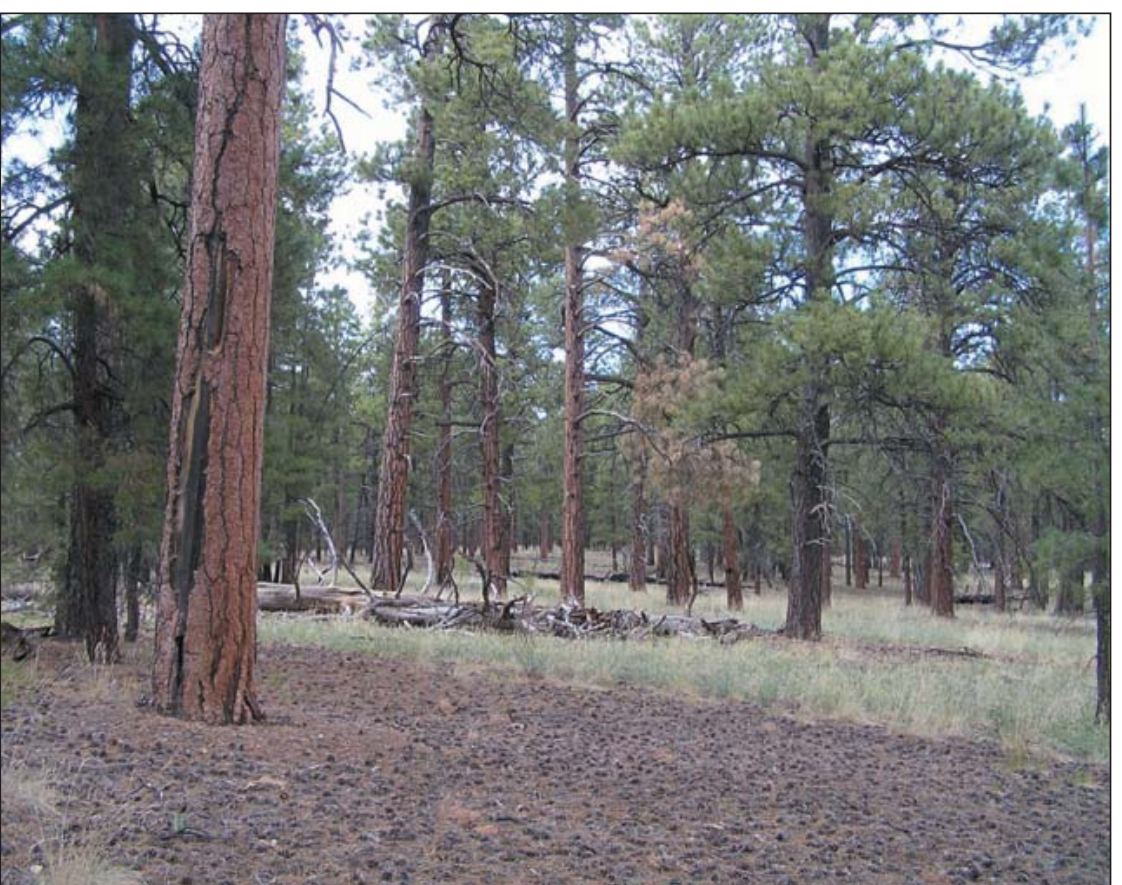

(Lindenmayer and Franklin 2002). Important reasons for this include an abundance of biological legacies, such as living organisms and dead tree structures, the migration and establishment of additional organisms adapted to the disturbed, early-successional environment, availability of nutrients, and temporary release of other plants from dominance by trees. Currently, early-successional forests (naturally disturbed areas with a full array of legacies, ie not subject to post-fire logging) and forests experiencing natural regeneration (ie not seeded or planted), are among the most scarce habitat conditions in many regions.

Our key findings on post-fire management are as follows. First, post-burn landscapes have substantial capacity for natural recovery. Re-establishment of forest following stand-replacement fire occurs at widely varying rates; this allows ecologically critical, early-successional habitat to persist for various periods of time. Second, post-fire (salvage) logging does not contribute to ecological recovery; rather, it negatively affects recovery processes, with the intensity of impacts depending upon the nature of the logging activity (Lindenmayer et al. 2004). Post-fire logging in naturally disturbed forest landscapes generally has no direct ecological benefits and many potential negative impacts (Beschta et al. 2004; Donato et al. 2006; Lindenmayer and Noss 2006). Trees that survive fire for even a short time are critical as seed sources and as habitat that sustains biodiversity both above- and belowground. Dead wood, including large snags and logs, rivals live trees in ecological importance. Removal of structural legacies, both living and dead, is inconsistent with scientific understanding of natural disturbance regimes and short- and long-term regeneration processes. Third, in forests subjected to severe fire and post-fire logging, streams and other aquatic ecosystems will take longer to return to historical conditions or may switch to a different (and often less desirable) state altogether (Karr et al. 2004). Following a severe fire, the biggest impacts on aquatic ecosystems are often excessive sedimentation, caused by runoff from roads, which may continue for years. Fourth, post-fire seeding of non-native plants is often ineffective at reducing soil erosion and generally damages natural ecological values, for example by reducing tree regeneration and the recovery of native plant cover and biodiversity (Beyers 2004). Non-native plants typically compete

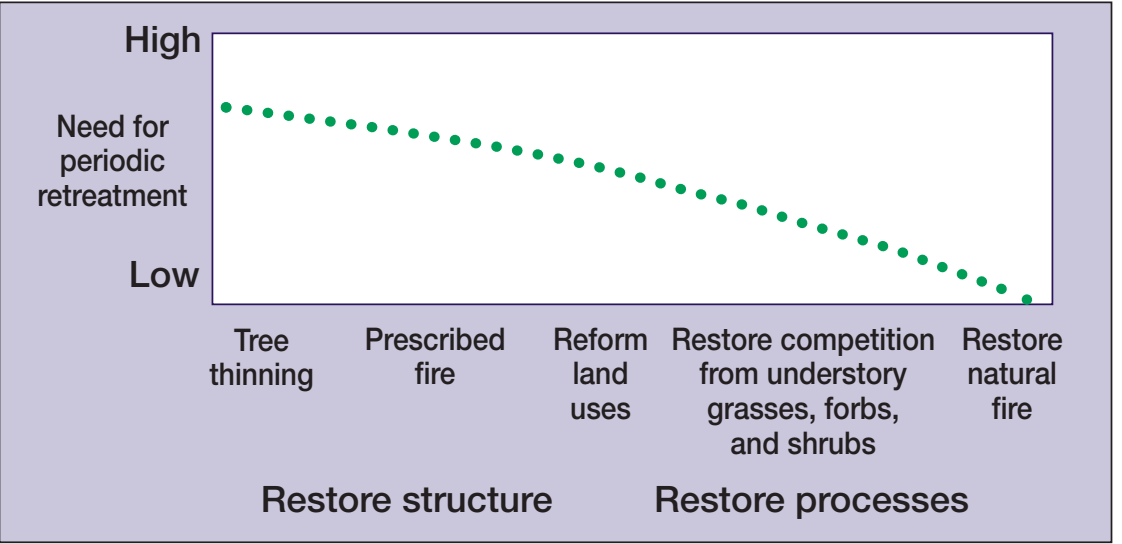

Figure 4. Forest restoration varies along a continuum from restoring structure (which requires periodic retreatment) to restoring potentially self-sustaining processes. 
with native species, reducing both native plant diversity and cover (Keeley et al. 2006). Fifth, the ecological importance of biological legacies and of uncommon, structurally complex early-successional stands argues against actions to achieve rapid and complete reforestation. Re-establishing fully stocked stands on sites characterized by low severity fire may actually increase the severity of fire because of fuel loadings outside the historical range of variability. Finally, species dependent on habitat conditions created by high severity fire, with abundant standing dead trees, require substantial areas to be protected from post-fire logging (Hutto 1995).

\section{More ecological science is needed in fire management}

Despite the complexity of fire ecology in western forests and uncertainty over the effects of particular management actions, the scientific basis for rational decisionmaking about fire has improved dramatically in recent years. It is time to systematically incorporate principles of ecological science and existing knowledge of individual forest ecosystems into forest fire and fuel policies.

One barrier to better use of ecological science is that individuals involved in developing fire policies and practices have tended to be specialists in fire and fuel management, not ecologists, conservation biologists, or other broadly trained scientists. It is not surprising, therefore, that current forest law does not adequately incorporate ecological considerations in its implementation and tends to promote a narrow definition of restoration that focuses almost exclusively on fuels (DellaSala et al. 2004; Schoennagel et al. 2004).

True ecological restoration requires the maintenance of ecological processes, native species composition, and forest structure at both stand and landscape scales. Because forests are highly variable over space and time, few universal principles exist for integrating insights from ecology and conservation biology into fire management policies. Nevertheless, one fundamental principle is that managed forests should not only support the desired fire regime but also viable populations of native species in functional networks of habitat (Hessberg et al. 2005). A common-sense conservation goal is to achieve forests that are low maintenance and require minimal repeated treatment. With time, in a landscape of sufficient size, the right end of the restoration continuum (Figure 4) could be reached, where natural fire maintains the system in the desired state. Indeed, wildland fire use is the cheapest and most ecologically appropriate policy for many forests. We envision a future where fire is seen by land managers and the public as the key to healthy forests, but where each forest and each patch of the forest mosaic is recognized for its individuality and managed accordingly. Above all, a guiding principle of forest management should be a precautionary approach that avoids ecological harm.

\section{Acknowledgements}

We thank the North American Section of the Society for Conservation Biology for sponsoring this project, with funding from the Wilburforce Foundation and $444 \mathrm{~S}$ Foundation.

\section{References}

Agee JK. 1993. Fire ecology of Pacific Northwest forests. Washington, DC: Island Press.

Agee JK. 1998. The landscape ecology of western forest fire regimes. Northwest Sci 72: 24-34.

Allen CD, Savage M, Falk D, et al. 2002. Ecological restoration of southwestern ponderosa pine ecosystems: a broad perspective. Ecol Appl 12: 1418-33.

Arno SF. 2000. Fire in western forest ecosystems. In: Brown JK and Smith JK (Eds). Wildland fire in ecosystems. Fort Collins, CO: Rocky Mountain Research Station. USDA Forest Service General Technical Report RMRS-GTR-42 - volume 2.

Belsky A and Blumenthal D. 1997. Effects of livestock grazing on stand dynamics and soils in upland forests of the interior west. Conserv Biol 11: 315-27.

Beyers JL. 2004. Post-fire seeding for erosion control: effectiveness and impacts on native plant communities. Conserv Biol 18: 947-56.

Beschta R, Rhodes J, Kauffman J, et al. 2004. Postfire management of forested public lands of the western United States. Conserv Biol 18: 957-67.

Brown PM, Kaufmann MR, and Shepperd WD. 1999. Long-term landscape patterns of past fire events in a montane ponderosa pine forest of central Colorado. Landscape Ecol 14: 513-32.

Brown RT, Agee JK, and Franklin JF. 2004. Forest restoration and fire: principles in the context of place. Conserv Biol 18: 903-12.

Covington WW and Moore MM. 1994. Southwestern ponderosa pine forest structure and resource conditions: changes since Euro-American settlement. J Forest 92: 39-47.

Covington WW, Fule PZ, Moore MM, et al. 1997. Restoration of ecosystem health in southwestern ponderosa pine forests. J Forest 95: 23-29.

DellaSala DA, Williams JE, Williams CD, and Franklin JF. 2004. Beyond smoke and mirrors: a synthesis of fire policy and science. Conserv Biol 18: 976-86.

Dombeck MP, Williams JE, and Wood CA. 2004. Wildfire policy and public lands: integrating scientific understanding with social concerns across landscapes. Conserv Biol 18: 883-89.

Donato DC, Fontaine JB, Campbell JL, et al. 2006. Post-wildfire logging hinders regeneration and increases fire risk. Science 311: 352

Ehle DS and Baker WH. 2003. Disturbance and stand dynamics in ponderosa pine forests in Rocky Mountain National Park, USA. Ecol Monogr 73: 543-66.

Gedalof Z, Peterson DL, and Mantua NJ. 2005. Atmospheric, climatic and ecological controls on extreme wildfire years in the northwestern United States. Ecol Appl 15: 154-74.

Habeck JR and Mutch RW. 1973. Fire-dependent forests in the northern Rocky Mountains. J Quaternary Res 3: 408-24.

Hemstrom MA and Franklin JF. 1982. Fire and other disturbances of the forests in Mount Rainier National Park. J Quaternary Res 18: 32-51.

Hessberg PF, Agee JK, and Franklin JF. 2005. Dry forests and wildland fires of the inland northwest USA: contrasting the landscape ecology of the pre-settlement and modern eras. Forest Ecol Manage 211: 117-39.

Heyerdahl EK, Brubaker LB, and Agee JK. 2001. Spatial controls of historical fire regimes: a multiscale example from the interior west, USA. Ecology 82: 660-78.

Hutto RL. 1995. Composition of bird communities following stand-replacement fires in northern Rocky Mountain (USA) 
conifer forests. Conserv Biol 9: 1041-58.

Karr JR, Rhodes JJ, Minshall GW, et al. 2004. The effects of postfire salvage logging on aquatic ecosystems in the American west. BioScience 54: 1029-33.

Kaufmann MR, Regan CM, and Brown PM. 2000. Heterogeneity in ponderosa pine/Douglas-fir forests: age and size structure in unlogged and logged landscapes of central Colorado. Can J Forest Res 30: 698-711.

Keeley JE, Allen CD, Betancourt J, et al. 2006. A 21st century perspective on postfire seeding. J Forest 104: 103-04.

Kipfmueller KF and Baker WL. 2000. A fire history of a subalpine forest in south-eastern Wyoming, USA. J Biogeogr 27: 71-85.

Lindenmayer DB, Foster DR, Franklin JF, et al. 2004. Saving forests or saving fiber? Salvage harvesting policies after natural disturbance impairs ecosystem and species recovery. Science 303: 1303.

Lindenmayer DB and Franklin JF. 2002. Conserving forest biodiversity. Washington, DC: Island Press.

Lindenmayer DB and Noss RF. 2006. Salvage logging, ecosystem processes, and biodiversity conservation Conserv Biol 20: 949-58.

McKenzie D, Gedalof Z, Peterson DL, and Mote P. 2004. Climatic change, wildfire, and conservation. Conserv Biol 18: 890-902.

Millar CI. 1998. Early evolution of pines. In: Richardson DM (Ed). Ecology and biogeography of Pinus. Cambridge, UK: Cambridge University Press.

Noss RF (Ed). 2000. The redwood forest. Washington, DC: Island Press.

Noss RF, Beier P, Covington WW, et al. 2006b. Integrating restoration ecology and conservation biology: a case study from ponderosa pine forests of the southwestern USA. Restor Ecol 14: 4-10.

Noss RF, Franklin JF, Baker WL, et al. 2006a. Ecology and management of fire-prone forests of the western United States. Society for Conservation Biology, North American Section. www.conbio.org/sections/namerica/napolicy.cfm. Viewed 21 Aug 2006.

Odion D, Frost E, Strittholt J, et al. 2004. Patterns of fire severity and forest conditions in the western Klamath Mountains, California. Conserv Biol 18: 927-36.

Pierce JL, Meyer GA, and Jull AJT. 2004. Fire-induced erosion and millennial-scale climate change in northern ponderosa pine forests. Nature 432: 87-90.
Romme WH and Despain DG. 1989. Historical perspective on the Yellowstone fires of 1988. BioScience 39: 695-99.

Rummell RS. 1951. Some effects of livestock grazing on ponderosa pine forest and range in central Washington. Ecology 32: 594-607.

Savage M and Swetnam T. 1990. Early nineteenth-century fire decline following sheep pasturing in a Navajo ponderosa pine forest. Ecology 71: 2374-78.

Schoennagel T, Veblen TT, and Romme WH. 2004. The interaction of fire, fuels, and climate across Rocky Mountain forests. BioScience 54: 661-76.

Shinneman DJ and Baker WL. 1997. Nonequilibrium dynamics between catastrophic disturbances and old-growth forests in ponderosa pine landscapes of the Black Hills. Conserv Biol 11: $1276-88$.

Skinner C. 1995. Change in spatial characteristics of forest openings in the Klamath Mountains of northwestern California, USA. Landscape Ecol 10: 219-28.

Smucker KM, Hutto RL, and Steele BM. 2005. Changes in bird abundance after wildfire: importance of fire severity and time since fire. Ecol Appl 15: 1535-49.

Spies TA, Hemstrom MA, Youngblood A, and Hummel S. 2006. Conserving old-growth forest diversity in disturbance-prone landscapes. Conserv Biol 20: 351-62.

Stephens S and Collins B. 2004. Fire regimes of mixed conifer forests in the north-central Sierra Nevada at multiple spatial scales. Northwest Sci 78: 12-23.

Taylor AH and Skinner CN. 2003. Spatial patterns and controls on historical fire regimes and forest structure in the Klamath Mountains. Ecol Appl 13: 704-19.

Turner MG, Romme WH, and Tinker DB. 2003. Surprises and lessons from the 1988 Yellowstone fires. Front Ecol Environ 1: 351-58.

Veblen TT, Kitzberger T, and Donnegan J. 2000. Climatic and human influences on fire regimes in ponderosa pine forests in the Colorado Front Range. Ecol Appl 10: 1178-95.

Wallace LL (Ed). 2004. After the fires: the ecology of change in Yellowstone National Park. New Haven, CT: Yale University Press.

Westerling A, Gershunov A, Brown T, et al. 2003. Climate and wildfire in the western United States. B Am Meteorol Soc 84: 595-604. 